UDK: 32.019.5:(529)+(497.4)

COPYRIGHT @: SAŠA ISTENIČ

\title{
The Role of Media in Democratic Consolidation of Taiwan and Slovenia
}

\author{
Saša ISTENIČ $\check{C}^{*}$
}

\begin{abstract}
The importance of the media in democracies has long been recognized. The media has often been seen as a preliminary mechanism of democratization process. Over the past 20 years, both Taiwan and Slovenia have been undergoing profound political changes, transforming from authoritarianism to democracy. This research will be a modest attempt to portray the significant role that media has played in the two countries' democratization processes and draw some interesting parallels between them.
\end{abstract}

Keywords: media, democratization, press freedom, Slovenia, Taiwan

\section{Izvleček}

Pomembnost medijev v demokracijah je že dolgo priznana. Mediji so pogosto videni kot predhoden mehanizem procesa demokratizacije. V zadnjih dvajsetih letih sta tako Tajvan kot Slovenija prestali temeljite politične spremembe in prešli iz avtoritativnega režima $\mathrm{k}$ demokraciji. Pričujoča skromna raziskava bo poskusila prikazati bistveno vlogo, ki so jo mediji odigrali $\mathrm{v}$ procesih demokratizacije teh dveh dežel in začrtala nekaj zanimivih vzporednic med njima.

Ključne besede: mediji, demokratizacija, svoboda tiska, Slovenija, Tajvan

\footnotetext{
* Saša Istenič, Assistant Professor, Department of Asian and African Studies, Faculty of Arts, University of Ljubljana; President, Taiwan Research Center. E-mail address: sasa@tajvan.si
} 


\section{Introduction}

Many authors have examined the complex relationship between the media and democracy from a variety of perspectives, both the impacts of politics on the media and vice versa, the influence of media on politics (see, among others, Baker 2002, Keane 1991, Lichtenberg 1990, Meyer and Hinchman 2002). Gunther and Mughan (2000) have conducted a very interesting comparative analysis to assess the media's contribution to the process of political change, particularly democratization, in several political systems that have been fundamentally transformed in the last two decades. Likewise, a number of authors attempted to examine the implications which the liberalization of a country's mass media environment has had upon Taiwan society. For instance, Berman (1992), Wei and Leung (1998), and Chen (1998) have all illuminated the integral role that the mass media have played in Taiwan's democratization process. However, the media environments of Slovenian and Taiwan have yet not been explored on a comparative basis. Since the two countries' recent liberalization and their comparable global-press-freedom indicators make it quite an interesting study, the author attempts to comparatively examine the interface between media and politics in Slovenia and Taiwan in order to illuminate some interesting parallels among them.

\section{Slovenia: Brief Historical and Political Background}

The ancestors of the Slovenes were Slavs who migrated from the Carpathians to the present-day territory after the decline of the Roman Empire, and founded the oldest known Slavic state in $7^{\text {th }}$ century, Carantania. During the $14^{\text {th }}$ century, most of the Slovene territory was put under the Habsburg rule. During this time the Slovenes emerged as a nation and forged their own identity, despite the oppression and sustaining pressure to assimilate. Slovenia became one part of the Kingdom of Serbs, Croats, and Slovenes (renamed the Kingdom of Yugoslavia in 1929) after the World War I, and a constituent republic of the Socialist Federal Republic of Yugoslavia following the World War II. The Communist Party of Yugoslavia and its leader Marshal Josip Broz (Tito) struggled to lead Yugoslavia as a communist federative republic under the ideals of socialism. Upon the collapse of the East European communist governments by the end of 1989, Yugoslavia lost the strategic and political weight it had during the Cold War as well as any semblance 
of unity. Slovenes were highly disappointed by the lack of political reforms and economic productivity within the Yugoslav federation. ${ }^{1}$ Consequently, the Slovenian government was first in declaring sovereignty and deciding to move to a multi-party political system, a market economy, and participation in Western Europe's move towards closer integration. The declaration of an independent Slovenia on June 25, 1991 actuated the Yugoslav government to deploy the Serbdominated federal army (Yugoslav People's Army) in an attempt to reassert control over the state border and block the Slovenian secession. The initiated war in Slovenia soon moved to Croatia (1991-95) and continued with particular ferocity in Bosnia and Herzegovina (1992-95). The wars claimed heavy losses and left behind a terrible legacy of physical ruins and psychological devastation.

Slovenia has been largely successful in achieving a relatively complete postwar recovery. It is the first post-Yugoslav state which successfully joined the EU and NATO and the first transition country to graduate from the borrower status to become adonor partner at the World Bank and to join the group of 30 most developed countries in the world. ${ }^{2}$ From January to June 2008, Slovenia was the first former communist bloc state to hold the EU's rotating presidency. In July 2010 Slovenia became a full member of the Organization for Economic Cooperation and Development (OECD).

As concerns its political changes, Slovenia, since its independence, was generally ruled by center-left governments, of which the most important component was the Liberal Democratic Party (LDS). In the 2004 parliamentary elections, the center-right Slovenian Democratic Party (SDS) unseated the LDSled government for the first time since 1991, and Janez Janša became the prime minister. In the 2007 presidential elections, Danilo Türk, a law professor and former diplomat, won the runoff as an independent candidate with the backing of the Social Democrats (SD) and several other parties. SD leader Borut Pahor, who became the prime minister, formed a coalition government with three small parties: the center-left Zares, the Democratic Party of Pensioners of Slovenia, and the once powerful LDS. However, the current domestic political picture is not rosy. Since June 2011, Slovenian government has been facing a political crisis:

\footnotetext{
${ }^{1}$ Slovenia represented only 8 percent of the population and yet produced 20 percent of Yugoslavia's national products and 25 percent of its export, while paying around 4.5 times more in federal taxes. Thus, they perceived they had little economic future in the state of Yugoslavia (see Ferfila 1991, 23). ${ }^{2}$ Slovenia joined the World Bank in February 1993, NATO on March 29, 2004 and EU on May 1, 2004.
} 
five ministers announced their resignations and this led to the fall of the government and the dissolution of parliament. The first early elections since independence from Yugoslavia in 1991 were held in December 2011. A new center-left party Positive Slovenia, headed by the mayor of Slovenia's capital, Zoran Janković, surprisingly won $29.5 \%$ of the vote against $25.9 \%$ for former premier Janša, the favourite to win. However, due to large differences in the programs of the parties, Janković failed to get a majority of legislators to support his nomination in the parliament. Instead, the five mostly centre-right parliamentary parties led by Janša's SDS, holding 50 seats in the 90 -seat parliament, proposed Janša as the prime minister. Consequently, it was Janša who in February 2012 officially took office. However, tangible progress towards a lasting political settlement is yet to be made.

\section{Slovenia's Media in the Early Democratization Process}

The Slovenian media scene is very diverse and heterogeneous. Its beginnings can be traced back to the $19^{\text {th }}$ century, when the print media, daily newspapers and periodicals in the Slovene language, started publishing in growing numbers. The media has always played an important role in Slovenian politics. In early 1980s, in particular, the media took a significant part in Slovenia's democratization process by articulating Slovene national questions and thereby creating a vibrant atmosphere of intellectual expression. Most liberal and provocative at that time were the magazines Nova revija and Mladina, which were relentlessly testing the borders of press freedom. In 1988 Mladina published classified documents of the Yugoslav federal army and League of Communists Central Committee, which revealed Belgrade's plans to stop the Slovene liberalization process. Shortly after, two journalists (among them Janez Janša), the magazine's editor and a Slovene sergeant in the Yugoslav army were arrested for "betraying military secrets". However, instead of a higher level of control on Slovenia, the Yugoslav army's authority had been diminished even further and only served to alienate the Slovenes from Yugoslavia. The Mladina trial became an important catalyst for the organisation of Slovene political movements and alternative political parties and also added strength to the idea that Slovenia should seek a greater degree of independence from the Yugoslav central authorities (Bukowski 1999, 82).

\footnotetext{
${ }^{3}$ The event has been referred to as the JBTZ trial, as it became known from the initials of the accused (Janša, Borštner, Tasić, Zavrl). See (Gow, 2000).
} 
Likewise, media played a crucial role during the Slovenian independence war in 1991. The media worked united in communicating the truth and getting the word through about what was happening in Slovenia, striving to keep people upto-date with recent developments in the war between Slovenia and the Yugoslav Army. Since it was unrealistic to expect Yugoslavia's only press agency Tanjug to provide fair and unbiased coverage of the events, the Slovene government worked fast in setting up the Slovenian Press Agency (STA). Arguably, without winning the media war and unveiling a different side of the story to the public, Slovenia would not come out of the war as a winner. ${ }^{4}$

\section{Taiwan's Media in the Early Democratization Process}

Similar to Slovenia under an authoritarian party-state system, Taiwan's media during the period of martial law (1949-1987) were politically restrained and served almost only to supplement the established political system and social values. The privilege to publish newspapers was given only to those loyal to the then authoritarian Chinese Nationalist Party (known as the Guomindang or KMT). Therefore, the so-called "two big newspapers" the United Daily (Lianhe Bao 聯合 報) and the China Times (Zhongguo Shibao 中國時報) and three television stations, Taiwan Television (Taiwan Dianshi 台灣電視), China Television (Zhongguo Dianshi 中國電視), and Chinese Television System (Zhonghua Dianshi 中華電視), together held more than a 90 percent share of the media market (Huang 2009, 4). Political forces "outside the party", the so called Dangwai group (Dangwai 黨外), could only voice their discontent through alternative and marginal media. Most influential earliest dissident magazines were the Taiwan Political Review (Taiwan Zhenglun 台灣政論), Free China (Ziyou Zhongguo 自由中國) and the Independent Evening Post (Zili Wanbao 自立晚報). However, confronting authorities often took its toll. Free China was forced to close in 1960 as it began to criticize the authoritarian rule and called for democratization while its editor-in-chief Lei Chen (Lei Zhen 雷震) and other opposition activists were charged with treason and jailed. The incident is one of the better known cases of the KMT government's suppression of press freedom during the martial law era. In the decades following the incident, little progress

\footnotetext{
${ }^{4}$ See an interview with Jelko Kacin, the then Minister of information (Žarkovič, 2011).
} 
was made in media freedom: publications were banned and writers and publishers were sent to prison. Taiwan Political Review suffered a similar fate. However, the journals' ideas of democracy and freedom had a great influence on later Dangwai magazines such as Formosa (美麗島). As the political opposition increased in force in 1970s and gained traction with the wider public, the KMT government struggled to meet this domestic challenge and opted to initiate a liberalization process. As Huang writes, the Dangwai magazines had at least two major influences on the development of Taiwan politics and the media: they gave impetus to the rise of the new Democratic Progressive Party (DPP), which was founded in 1986 and gave names to its subsequent factions; they also influenced the journalistic style and attitude of Taiwan's mainstream media (Huang 2009, 67). Once the martial law and subsequently the ban on newspapers and magazines were lifted, Taiwan and its media have embarked on a new era. The KMT's monopoly on television and radio broadcasting was challenged by mushrooming underground stations, and its control had gradually lost impact. In 1993, the increasing pressure compelled the Government Information Office to grant licenses for new radio stations and liberalize the cable TV industry. The abolishment of the Publication Act in 1999 further eliminated government control of public media. Gradually, media limits were phased out. However, notwithstanding Taiwan's transition to democracy, performance of the media has been criticized even after the liberalization.

\section{Taiwan's Media Today}

Since the lifting of martial law in 1987, Taiwan's media has been characterized first by freedom, and then intense commercialization, rapidly followed by fierce market competition. At present, Taiwan's media is comprised of over $200 \mathrm{TV}$ channels, 170 radio stations, 2,000 newspapers and 7,000 magazines (GIO, 2011). Therefore, Taiwan's media competition is undeniably among the most intensive ones in the world.

As already pointed out, the KMT had a complete authority over Taiwan's media up to the early 1990s. However, the DPP's relations with the media have also raised some questions. In spite of its advocacy for media freedom, the DPP has also recurrently engaged in squabbles with the media. Similar to Slovenia, while in theory, political forces and parties have lost direct control of the media, in 
practice however, all parties, and especially the ruling party at any given time have continued to seek to control the media. The KMT's domination over the media did not relinquish even after being voted out of power in 2000, whereas the DPP, while pledging to support the separation of political parties and media, in fact used governmental resources to manipulate the media, or even threatened them with judicial power. ${ }^{5}$ As a result, for the sake of money, a number of media have tried to minimize criticism of government policies and exaggerated its achievements. In order to make an end to such interferences, the legislation that took effect in 2005 banned government agencies, the military and political parties from investing in or operating radio and television stations. Moreover, from the beginning of this year, the new amendment to the Budget Act strictly prohibits the practice of embedded advertisement by all government agencies, as well as by state-funded or state-run enterprises.

Regardless of being listed among those with freest media environments in Asia, Taiwanese media have often been criticized as politically biased, politicized and even more, as hampering further democratic consolidation. One concern is that partisanship is taken to extremes, leading some critics to argue that the media have degenerated into mouthpieces of political parties. For this reason, Taiwan's media have been labelled as "mad dogs" in a democratic society and have even been viewed as a threat to the legitimacy of Taiwan's democratic system (Magnier 2005; Huang 209, 2; and Hwang 2011). In addition to the implications of the political bickering between the pan-blue and the pan-green camps, most criticisms of Taiwan's media also entail the question of sensationalism and commercialism, and consequently, lack of objectivity and professionalism.

\section{Slovenia's Media Today}

Today there are about 1600 media outlets registered in Slovenia according to Slovenia's institute for market and media research (Mediana 2010). Among them, there are $79 \mathrm{TV}$ channels, 95 radio stations and 1178 print media. The largest of these are the public service broadcaster Radio-Television Slovenia, the commercial broadcaster Pro Plus, and three print publications-Delo, Dnevnik and Večer - which, interestingly, are all the old newspapers from the communist times metamorphosed into the so-called nonpartisan independent newspapers amid the

\footnotetext{
${ }^{5}$ For a detailed list of some of the incidents between media and the ruling party, see Huang 2009, 14 .
} 
new media regulation and privatization in 1990. There is only one main news agency in Slovenia, Slovenian Press Agency (STA), which is an important source of information for smaller media.

In the last decade, Slovene media independence has been a point of contention between the center-right parties on one side and the center-left on the other, with journalists tilting towards either left or right. Notwithstanding the establishment of parliamentary democracy, market economy and completed privatization process in the 1990s, a large number of Slovenian media companies are still directly and indirectly owned and controlled by the state. Consequently, changes of the government are followed by transformation of media legislature and changes in media, ownership and editorial policy. ${ }^{6}$ For instance, after a ruling coalition of right-wing parties was set in 2004 for the first time since 1992, alterations in media regulation have coincided with changes in media ownership. And, as soon as the left-wing government won the parliamentary elections in 2008, the debate on new changes of media laws and media regulation system was once again stirred up. Consequently, adoption of the new Act on Radio-Television Slovenia ensued, but days later the opposition parliamentary parties initiated a referendum, which was then held in December 2010. However, the voters rejected the Act and ended the debate over the status of the public broadcaster. ${ }^{7}$

Freedom of the press and other forms of public communication and expression are ensured by the Constitution and The Act on the Media provides rules and regulations for the entire media sphere. Since insulting public officials is prohibited by law, officials have the right to prosecute journalists whenever they feel defamed. Consequently, Slovene journalists have been under much of pressure from one or the other political side, frequently claiming that political reality is portrayed in a non-objective way or that their views are misrepresented. In recent years, there have been a number of reports of self-censorship and increasing government pressure on both media outlets and advertisers. Pressure comes from both political and business arena and the number of lawsuits against journalists in Slovenia has been on the rise. In the latest Report on the Freedom of the Press in Slovenia for 2010, the Association of Journalists and Commentators

\footnotetext{
${ }^{6}$ For a more thorough analysis of the changes of media ownership and the role of politics in media see the monitoring reports on the work of mass media in Slovenia by Media Watch series, available online at Mirovni inštitut.

${ }^{7}$ Only 14,8 percent of voters participated in the referendum on the act, which was voted down by a margin of 44,6 percent.
} 
(ZNP) noted the increasing pressure exerted by the ruling power on the Slovenian media (The Association of Journalists and Commentators 2011). Criminal prosecutions against the journalists in order to suppress criticism of their work, as they argue, represent not only an attack on the freedom of the public word but also on the fundamental values of democracy. Journalists regard the lack of media pluralism as the key issue regarding the freedom of the press in Slovenia. Since the editorial policies of major Slovenian newspapers are all supported by the left-wing ruling parties, these can also exert influence through state-owned enterprises, which are the largest advertisers in the media. Therefore, journalists have repeatedly raised their voice in order to draw international attention to Slovenia's media environment.

\section{Conclusion}

Two decades after the end of the martial law in Taiwan and two decades after Slovenia's independence, Taiwanese and Slovenian people enjoy fundamental rights of various kinds of freedom and civil liberties. In both countries, the media have created space for opposition parties, which in turn helped to institutionalize a culture where critical views are tolerated. Media freedom is an important link in democracy. International ratings of Slovenia's and Taiwan's media freedom have fluctuated over the years. At present, recognized as "free", they both share the $47^{\text {th }}$ place in the global press freedom according to the survey conducted by Washington D.C.-based Freedom House. ${ }^{8}$ Notably, upon the second change in the ruling parties of both countries, their ranking in the same survey has continuously declined until this year, when the rating moved both countries up one notch from the year before. Such fluctuations justly point out concerns over the two countries' media environment. Apparently, political factors in both countries have significant implications on the development of the media and freedom of the press, especially at sensitive times of political transition. Due to political pressure editors tempt to cut down on reports critical to the government on the one hand, to avoid potential lawsuits, and on the other, due to commercial concerns. In Slovenia and Taiwan in particular, the extreme political polarization had great implications on media quality. In other words, involvement in political struggles tarnished the media reputation. Since untrustworthy media cannot have a positive role in a country's

\footnotetext{
${ }^{8}$ See Freedom House (2011), "Freedom of the Press" surveys.
} 
democratization process, calls for greater media self-regulation and accountability are growing louder over the recent years.

To sum up, the relationship between the media and democratization is an important yet a highly complex issue. This paper has illuminated an important role that media plays in explaining Slovenia's and Taiwan's contentious state of democracy and politics. On the one hand, the democratic system allows a high degree of press freedom as any opposition is granted a legal voice. On the other hand, the system also enables democracy to affect information content. For both Slovenia and Taiwan, two decades in the new democratic atmosphere have not been long enough for professional journalism to develop. In order to serve democracy, the media will need to increase transparency and implement certain control mechanisms to ensure uniform standards throughout the country's media sector.

\section{References}

Asante, Clement. 1997. Press Freedom and Development: A Research Guide and Selected Bibliography. Westport, Connecticut: Greenwood Press.

The Association of Journalists and Commentators. 2011. Report on the Freedom of the Press in Slovenia for 2010. Ljubljana. Accessed September 3, 2011. http://www.znp.si/index.php/english-texts-mainmenu-27/236-report-on-the-freedomof-the-press-in-slovenia-for-2010

Baker, C. Edwin. 2002. Media, Markets, and Democracy. Cambridge: Cambridge University Press.

Berman, Daniel K. 1992. Words like Coloured Glass: the Role of the Press in Taiwan's Democratization Process. Boulder, CO.: Westview Press.

Bukowski, Charles. 1999. "Slovenia's Transition to Democracy: Theory and Practice." East European Quarterly 33(1): 69.

Chen, Shue Yun. 1998. "State, Media, and Democracy in Taiwan.” Media, Culture and Society 20(1): 11-29.

Ferfila, Bogomil. 1991. "Yugoslavia: Confederation of Disintegration?" Problems of Communism 40(4): 18-40.

Freedom House. 2011. "Freedom of the Press." Washington D.C.: Freedom House. Accessed September 3, 2011. http://www.freedomhouse.org.

Government Information Office (GIO). 2011. "The Republic of China Yearbook 2010." http://www.gio.gov.tw/taiwan-website/5-gp/yearbook/15MassMedia.pdf. 
Gow, James, and Carmichael, Cathie. 2000. Slovenia and the Slovene: A Small State and the New Europe. Bloomington and Indianapolis: Indiana University Press.

Gunther, Richard, and Mughan, Anthony, eds. 2000. Democracy and the Media: A Comparative Perspective. Cambridge: Cambridge University Press.

Huang, Ching-Lung 黃清龍. 2009. “The Changing Roles of the Media in Taiwan's Democratization Process.” The Brookings Institution CNAPS Working Paper. Washington DC: The Brookings Institution, 1-20.

Hwang, Jim. 2011. "The Battle Continues." Taiwan Review, August 1. Accessed August 2, 2011. http://taiwanreview.nat.gov.tw/ct.asp?ctNode $=1446 \& x$ Item $=171058 \& \mathrm{mp}=1$.

Keane, John. 1991. The Media and Democracy. Cambridge: Polity Press.

Lichtenberg, Judith, ed. 1990. Democracy and the Mass Media: A Collection of Essays. Cambridge: Cambridge University Press.

Magnier, Mark. 2005. “They Can't Handle the Truth.” Los Angeles Times, February 28. Accessed September 14, 2011. http://articles.latimes.com/2005/feb/28/world/fghounds28.

Mediana. 2010. "Redna letna raziskava stanja medijskega pluralizma v Republiki Sloveniji v letu 2009 na področju slovenskih tiskanih, radijskih in televizijskih medijev ter elektronskih publikacij (Annual Research on the State of Media Pluralism in the Republic of Slovenia in the year 2009)." Accessed September 3, 2011. http://www.mk.gov.si/fileadmin/mk.gov.si/pageuploads/Ministrstvo/raziskaveanalize/mediji/MZK_pluralizem_29042010-POPRAVEK.pdf.

Meyer, Thomas, and Hinchman, Lew. 2002. Media Democracy: How the Media Colonize Politics. Cambridge: Polity Press.

Mirovni inštitut. 1998-2011. Media Watch. Ljubljana: Mirovni inštitut. Accessed September 3, 2011. http://mediawatch.mirovni-institut.si/.

Wei, Ran, and Leung, Louis. 1998. "A Cross-Societal Study on the Role of the Mass Media in Political Socialization in China and Taiwan." Gazette 60(5): 377-93.

Žarkovič, Vesna. 2011. "Jelko Kacin-Interview." Government Communication Office. Accessed September 5, 2011. http://www.twenty.si/first-20-years/overview/beforeand-now/bold-and-united/ 